Review

\title{
SWIMMING IN THE BREEDING POOL: PARTNERING FOR CONSERVATION OF PLANT GENETIC RESOURCES THROUGH CROP GERMPLASM ENHANCEMENT
}

\author{
Rodomiro Ortiz \\ Swedish University of Agricultural Sciences, Department of Plant Breeding and Biotechnology, \\ Sundsvagen 14, Box 101, SE 23053, Alnarp, SWEDEN; \\ rodomiro.ortiz@slu.se
}

Communicated by Roland von Bothmer

\begin{abstract}
Substantial and sustainable increases in productivity of all crops are needed to meet the predicted demand for food, feed, fibres, flowers, fuels, fun, feed-stocks and pharmaceuticals of this $21^{\mathrm{st}}$ century bio-based economy. Plant breeding is vital for protecting the yield gains made to date, and for further increasing the genetic yield potential of all crops. As a result of the Green Revolution, global productivity of the main food staples steadily rose since the 1960s. Such achievements ensued from crop genetic enhancement partnerships. They are models for illustrating partnering for exchange, evaluation, release and use of plant genetic resources worldwide. These partnerships include national agricultural research institutes and international agricultural research centres. For many decades the global wheat yield increased due to an effective International Wheat Improvement Network (IWIN), which deployed cutting-edge science alongside practical multi-disciplinary applications, resulting in the development of bred-germplasm that has improved food security and the livelihoods of farmers in the developing world. IWIN operates field evaluation trials in more than 250 locations of 100 countries for testing breeding wheat lines across many environments. The International Network for Genetic Evaluation of Rice (INGER) has become an integral component of rice breeding programmes: every year partners provide about 1000 genetically diverse breeding lines, which have been grown in about 600 experiment stations from 80 countries. The Latin American Maize Programme (LAMP) has assessed national germplasm, facilitated the exchange of genetic resources across the continent, and its core subset has been made available to encourage further use in broadening maize genetic resources. For example, the Germplasm Enhancement of Maize (GEM) project has used LAMP-selected landraces in crosses with elite temperate maize lines provided by North American private companies, to introgress useful genetic diversity into US maize germplasm, with the aim to broaden the genetic base of "corn-belt" hybrids.
\end{abstract}

Key words: CGIAR, maize, pre-breeding, rice, wheat.

\section{INTRODUCTION}

The world population increases by approximately 78 million people annually. About 1 billion humans suffer from hunger and 3 billion malnourished people live with less than 2 USD daily. Anthropogenic climate change continues to affect food output and quality while the world continues facing an increasing demand for nutritious and quality food, feed, fibre and fuel (Hubert et al., 2010). There will be 1.7 billion more people to feed by 2030, but with a declining ratio of arable land between 40 and $55 \%$.

The main elements of $21^{\text {st }}$ century agriculture are sustainable intensification of agro-systems for a changing climate, agro-biodiversity for promoting sustainability and adaptation to climate change, agro-biotechnology innovations for sustainable agriculture, diversification of intensive agro- systems, food quality and safety for human nutrition and health, and "balancing" agriculture and environment towards a wealthy and healthy society (Ortiz, 2011a). Furthermore, agriculture needs eco-efficient and resilient systems to meet end-user demands. Such agro-systems should provide enough and safe food, enhance human health through better nutrition for the poor and well-balanced diets for the rich, diminish the use of fossil fuels, adapt to extreme weather and water stresses, reduce environmental degradation and decline in the quality of soil, water, air and land resources in an increasingly urbanised world, and be a source of raw materials for bio-energy and a bio-based economy in this $21^{\text {st }}$ century.

Agro-biodiversity components act similarly in agro-systems as biodiversity in other ecosystems: genetic diversity or ge- 
netic variation within the species, species diversity or variation existing for species in a specific region, and ecosystem diversity comprising variation between agro-systems within a region (Ortiz, 2011b). Agro-biodiversity provides a means for intensifying sustainable crop yields and for adapting crops to climate change, e.g. genetic broadening helps to introgress new genes in breeding populations. Intra-specific crop diversification (i.e., mixture of landraces or cultivars) allows to control effectively pathogens and pests over large areas, and genetically enhanced seed-embedded technology contributes to adaptation to variable environments due to changing climate. Sustainable crop genetic enhancement consists of identifying a useful character, manipulating its genetic variation, putting genes into a usable form, using DNA markers to monitor chromosomal changes and as selection aid, and genetic engineering to enhance useful variation if not available in crop gene pools.

One large impact of plant breeding that changed human history arose in the Green Revolution through the research, development, and technology transfer that occurred between 1943 and the late 1970s (Ortiz, 2011c). Dwarfing, photoperiod insensitive genes and host plant resistance genes to pathogens and pests were bred for various crops during the Green Revolution (Trethowan et al., 2007). The Green Revolution increased production in agriculture in many nations of Asia and Latin America. Crop yields in the developing world would have been at least $20 \%$ less and food prices about $19 \%$ higher than they were in 2000 without the innovations of the Green Revolution (Evenson and Gollin, 2003). Calorie consumption would have dropped by about $5 \%$ and the number of malnourished children would have increasing by at least $2 \%$; i.e., the Green Revolution helped to improve the health status of 32 to 42 million pre-school children. Net effect of high yields due to the Green Revolution avoided emissions of up to 161 gigatons of carbon (GtC) (590 Gt $\mathrm{CO}_{2} \mathrm{e}$ ) since 1961 (Burney et al., 2010).

Plant breeding includes two phases: the collection and generation of variation and reproductive potential followed by selection of the most productive surviving genotypes (Allard, 1999). Germplasm enhancement (also known as prebreeding) is the early component of sustainable plant breeding that deals with identifying a useful character, "capturing" its genetic diversity, and putting genes into a usable form (Ortiz, 2002). It includes both the introgression of one or a few alleles and large incorporation of exotic sources (Simmonds, 1993), e.g. crop wild relatives or landraces. Germplasm enhancement can be considered as the transfer or introgression of genes and gene combinations from nonadapted sources into breeding material. It should be also regarded as a long-term activity for selection of local adaptation and yield potential, and can incorporate DNA markers to monitor chromosomal changes and aid in selecting desired genotypes.

There have been various global partnerships that illustrate successful partnering for the exchange, evaluation, release and use of plant genetic resources worldwide. This article describes three of them, which include both national agri- cultural research institutes and international agricultural research centres partnering for the genetic enhancement of the main cereals that feed the world: wheat, rice and maize.

\section{THE INTERNATIONAL WHEAT IMPROVEMENT NETWORK}

This international network dates back to the 1940s. i.e., more than 20 years before it was officially founded as an international organisation in 1966 (Ortiz et al., 2007). It began as a research project sponsored by the Government of Mexico and the Rockefeller Foundation dedicated to improving maize, beans and wheat, and later potato. Initially its research and training programme focused on Mexico, but soon began collaborating with other countries, especially in South America. In these early years, key organisational principles emerged, which became later on central to the entire network dealing with international agriculture (known today as the CGIAR Consortium). The late 1970 Nobel Peace Laureate Norman E. Borlaug led the original wheat programme, which evolved into an alliance between national agricultural research systems, the Centro Internacional de Mejoramiento de Maíz y Trigo (CIMMYT, Mexico) the International Centre for Agricultural Research in the Dry Areas (ICARDA, Syria) and advanced research institutes.

This network deployed cutting-edge science alongside practical multi-disciplinary applications, resulting in the development of genetically enhanced wheat germplasm, which has improved food security and the livelihoods of farmers in the developing world (Ortiz et al., 2008). The spring wheat germplasm bred in Mexico under the leadership of Borlaug was further used for launching the Green Revolution in India, Pakistan, and Turkey (Reynolds and Borlaug, 2006). The network was broadened during the 1970s to include Brazil, China, and other major developing country wheat producers. It resulted in wheat cultivars with broader host plant resistance (especially to rusts), better adaptation to marginal environments, and tolerance to acid soils.

Today this international alliance operates field evaluation trials in more than 250 locations in around 100 countries for testing improved lines of wheat in different environments. The number of wheat cultivars released annually in the developing world doubled to more than 100 cultivars by the early 1990s due to this networking and the strengthening of national capacity (Lantican et al., 2005). The widespread adoption of newly bred wheat cultivars, especially in South Asia and Latin America, due to yield increases led to 50\% average annual rates of return for investments (Alston et al., 2000). The urban poor also benefited significantly because grain harvest increases drove wheat prices down.

Every year, nursery sets and trials are sent worldwide to various researchers, who share their data from these trials for cataloguing and analysis. The returned data are used to identify parents for subsequent crosses and to incorporate new genetic variability into advanced wheat lines that are 
consequently able to cope with the dynamics of abiotic and biotic stresses affecting wheat farming systems. The full pedigrees and selection histories are known and phenotypic data cover yield, agronomic, pathological and quality data (Ortiz et al., 2008).

Crossa et al. (2007) used mapped diversity array technology (DArT) markers to identify associations with resistance to stem rust, leaf rust, yellow rust, and powdery mildew, plus grain yield in five historical wheat international multienvironment trials from CIMMYT. They used two linear mixed models to assess marker-trait associations incorporating information on population structure and covariance between relatives, and found that most of the associated markers were in genomic regions where previous reports had found genes or quantitative trait loci influencing the same traits, thereby providing an independent validation of this approach.

CIMMYT and ICARDA have given priority in recent years to continue broadening the genetic base of wheat (Ortiz et al., 2008). They resynthesised hexaploid bread wheat using putative tetraploid and diploid ancestors of this crop, i.e., durum wheat with Aegilops tauschii, the donor of the D genome. Some re-synthesised wheat lines are becoming an interesting source of variation for adaptation to drought- and heat-prone environments (Trethowan et al., 2002), as well as for host plant resistance to pathogens and pests. An enhanced knowledge of wheat evolution provides a way for improving the manipulation of genetic diversity through re-synthesis, which should be seen as the first step of an evolutionary breeding strategy for wheat improvement that broadens the genetic base of the cultigen pool.

\section{INTERNATIONAL NETWORK FOR GENETIC EVALUATION OF RICE AND BEYOND}

This network, better known by its acronym INGER, has been acknowledged as a global model for the exchange, evaluation, release, and use of rice genetic resources. INGER was established in 1975 as a consortium of national agricultural research systems of rice-growing countries and Centres of today's CGIAR Consortium. It was initially founded as the International Rice Testing Programme, and became an integral component of national rice breeding programmes. INGER partners can share rice breeding lines. This network facilitated the release of 667 cultivars worldwide, which translated into 1.5 billion USD of economic benefits. It was estimated that ending INGER could lead to reduction of the number of rice cultivars by 20 every year, and to an economic loss of 1.9 billion USD (Evenson and Gollin, 1997). Further analysis by Jackson and Huggan (1993) has shown how genetic conservation of landraces could lead to significant gains in rice breeding.

The new rice for Africa (NERICA) is another successful example of mainstreaming germplasm enhancement in plant breeding in a CGIAR Consortium Centre. NERICA ensues from crossing Asian rice Oriza sativa and African rice
O. glaberrima, and using embryo rescue for producing hybrids between them. Several cycles of backcrossing to the $O$. sativa parent led to offspring with strong fertility (Jones et al., 1997b). True-breeding lines for further testing were derived after anther-culture and chromosome doubling (Jones et al., 1997a). The NERICA cultivars benefit from the high yields of Asian rice combined with the adaptation of African rice to harsh growing environments (Johnson et al., 1998; Dingkuhn et al., 1999), which may become more widespread due to ongoing climate change. A participatory varietal selection (PVS) approach was adopted to identify NERICA cultivars that were best suited to rice farming in Africa. A community-based seed system, which was built on farmers' own seed-saving practices with complementary training in seed technologies, complemented this PVS approach. As a result, NERICA quality seeds became available to African farmers in just four years vis-à-vis the seven years often needed for formal seed system release. African farmers grew about 200,000 ha NERICA in rain-fed uplands by the end of the last decade. NERICA offers early maturity (30 days before local cultivars), it out-yields local cultivars with little use or lack of fertiliser, allows intensive cropping and can escape drought.

The Centres of the CGIAR Consortium and partners worldwide continue assessing rice genetic diversity and developing new breeding pools. They recently launched a Global Rice Science Partnership (GRiSP) as a new CGIAR research programme that uses genetic resources and diversity as the foundation for enhancing durable host plant resistance to pathogens and pests, and adaptation to stress-prone environments. Their work ranges from conservation to use of rice genetic resources, including research on phenotypegenotype associations that could provide further insights into gene functions and lead to genomics-based breeding.

\section{MAIZE'S LAMP AND GEM}

The Latin American Maize Programme (LAMP) was established as a partnership between Latin America and the USA to assess national germplasm and facilitate the exchange of maize genetic resources across the continent (Salhuana et al., 1997). The United States Department of Agriculture, the participating national agricultural research systems and a multinational seed corporation provided the funding. The aim of LAMP was to obtain information about the performance of maize germplasm and to share it with plant breeders for developing genetically enhanced open pollinated and hybrid cultivars. The maize germplasm was tested for agronomic characteristics from sea level to $3300 \mathrm{~m}$, and from $41^{\circ} \mathrm{N}$ to $34^{\circ} \mathrm{S}$ across 32 locations in the first stage and in 64 locations (two per region) in stage II. These locations were clustered according to five homologous areas: lowland tropics, temperate and three altitudes.

There were five LAMP breeding stages (Salhuana et al., 1997). In the first stage, 14,847 accessions belonging to a region were planted for evaluation in trials using a randomised complete block design with two replications of $10 \mathrm{~m}^{2}$ 
plots at a single location, which was environmentally similar to that from where these landraces were originally collected. The next step included the assessment of the upper quintile $(20 \%)$ of those accessions evaluated for agronomic performance in the previous stage. These accessions were planted in two locations with two replications, and the upper 5\% were further selected according to their performance. These best selected accessions of each country were interchanged among regions belonging to the same homologous area in the third stage. They were tested in two locations with two replications in each region. The selected accessions from the same homologous area were mated with the best tested accession of the region in an isolated field within each region. In the fourth stage, combining ability tests of 268 selected accessions were carried out with a local tester using two replications at two locations within each region. The elite maize germplasm was integrated into breeding programmes in the fifth stage, which was the last. The best cross combinations and heterotic pools were also determined by LAMP. Maize breeders obtained access to the most promising accessions identified by LAMP to widen the crop genetic base. A LAMP core subset has been made available for encouraging further use in broadening of maize genetic diversity (Taba et al., 1999).

The Germplasm Enhancement of Maize (GEM) was set up to introgress useful genetic diversity from Latin American maize races and other tropical maize donor sources (lines and hybrids) into US maize germplasm, to broaden the genetic base of the "corn-belt" hybrids (Balint-Kurti et al., 2006; Goodman, 2005). GEM owes its existence to LAMP because it has used the Latin American landrace accessions selected by LAMP in crosses with elite temperate maize lines from the private seed companies in North America (Salhuana and Pollak, 2006). GEM used a pedigree breeding system to develop $\mathrm{S}_{3}$ lines. The GEM breeders arranged their crosses into non-Stiff Stalk and Stiff Stalk heterotic groups (Ortiz et al., 2010).

LAMP provided the first step through the sharing of information needed to select genebank accessions for further germplasm enhancement. GEM completed the process by returning to genetically enhanced breeding materials derived from the genebank accessions. This improved germplasm can be further used in maize breeding in the USA and elsewhere. LAMP and GEM are nice examples of international and national public-private partnerships in crop germplasm enhancement.

\section{REFERENCES}

Allard, R. W. (1999) Principles of Plant Breeding. 2nd edn. New York: John Wiley \& Sons. $264 \mathrm{pp}$.

Alston, J. M., Marra, M. C., Pardey, P. G., Wyatt, T. J. (2000). Research returns redux: A meta-analysis of the returns to agricultural R\&D. Austr. J. Agric. Resour. Econ., 44, 185-215.

Balint-Kurti, P., Blanco, M., Milard, M., Duvick, S., Holland, J., Clements, M., Holley, R., Carson, M. L., Goodman, M. (2006). Registration of 20 GEM maize breeding germplasm lines adapted to the southern U.S. Crop Sci., 46, 996-998.
Burney, J. A., Davis, S. J., Lobell, D. B. (2010). Greenhouse gas mitigation by agricultural intensification. Proc. Natl. Acad. Sci., 107, 12052-12057.

Crossa, J., Burgueño, J., Dreisigacker, S., Vargas, M., Herrera, S., Lillemo, M., Singh, R. P., Trethowan, R., Franco, J., Warburton, M., Reynolds, M., Crouch, J. H., Ortiz, R. (2007). Association analysis of historical bread wheat germplasm using additive genetic covariance of relatives and population structure. Genetics, 177, 1889-1913.

Dingkuhn, M., Johnson, D. E., Sow, A., Audebert, A. Y. (1999). Relationships between upland rice canopy characteristics and weed competitiveness. Field Crops Res., 61, 79-95.

Evenson, R. E., Gollin, D. (1997). Genetic resources, international organizations, and improvement in rice varieties. Econ. Dev. Cultural Change, $\mathbf{4 5}$, 471-500.

Evenson, R. E., Gollin, D. (2003). Assessing the impact of the Green Revolution, 1960 to 2000. Science, 300, 758-762.

Goodman, M. M. (2005). Broadening the U.S. maize germplasm base. Maydica, 50, 203-214.

Hubert, B., Rosegrant, M., van Boekel, M. A. J. S., Ortiz, R. (2010). The future of food: Scenarios for 2050. Crop Sci., 50, S1-S18.

Jackson, M. T., Huggan, R. D. (1993). Sharing the diversity of rice to feed the world. Diversity, 9, 22-25.

Johnson, D. E., Dingkuhn, M., Jones, M. P., Mahamane, M. C. (1998). The influence of rice plant type on the effect of weed competition on Oryza sativa and Oryza glaberrima. Weed Res., 38, 207-216.

Jones, M. P., Dingkuhn, M., Aluko, G. K., Semon, M. (1997a). Interspecific Oryza sativa L. $\times$ O. glaberrima Steud. progenies in upland rice improvement. Euphytica 92, 237-246.

Jones, M.P., Mande, S., Aluko, K. (1997b). Diversity and potential of Oryza glaberrima Steud. in upland rice breeding. Breed. Sci. 47, 395-398.

Lantican, M. A., Dubin, M. J., Morris, M. L. (2005). Impacts of International Wheat Breeding Research in the Developing World, 1988-2002. México D.F.: Centro Internacional de Mejoramiento de Maíz y Trigo.

Ortiz, R. (2002). Germplasm enhancement to sustain genetic gains in crop improvement. In: Managing Plant Genetic Diversity (pp. 275-289). Engels, J. M. M., Ramanatha Rao, V., Brown, A. H. D., Jackson, M. T. (eds.). Wallingford, Oxon, United Kingdom: CAB International; Rome, Italy: International Plant Genetic Resources Institute,

Ortiz, R. (2011a). Re-visiting the Green Revolution: Seeking innovations for a changing World. Chron. Horticult., 51 (1), 6-11.

Ortiz, R. (2011b). Agrobiodiversity management for climate change. In: Agrobiodiversity Management for Food Security: Critical Review (pp. 189-211). Lenné, J., Wood, D. (eds.). Wallingford, United Kingdom: CAB International.

Ortiz, R. (2011c). The way ahead: From science to policy; coordinating efforts in a global world. In: Crop Stress Management and Global Climate Change (pp. 191-203). Wallingford, United Kingdom: CAB International.

Ortiz, R., Mowbray, D., Dowswell, C., Rajaram, S. (2007). Norman E. Borlaug: The humanitarian plant scientist who changed the world. Plant Breed. Rev., 28, 1-37.

Ortiz, R., Braun, H. J., Crossa, J., Crouch, J. H., Davenport, G., Dixon, J., Dreisigacker, S., Duveiller, E., He, Z., Huerta, J., Joshi, A. K., Kishii, M., Kosina, P., Manes, Y., Mezzalama, M., Morgounov, A., Murakami, J., Nicol, J., Ortiz-Ferrara, G., Ortiz-Monasterio, J. I., Payne, T. S., Peña, R. J., Reynolds, M. P., Sayre, K. D., Sharma, R. C., Singh, R. P., Wang, J., Warburton, M., Wu, H., Iwanaga, M. (2008). Wheat genetic resources enhancement by the International Maize and Wheat Improvement Center (CIMMYT). Genet. Resour. Crop Evol., 55, 1095-1140.

Ortiz, R., Taba, S., Chávez Tovar, V. H., Mezzalama, M., Xu, Y., Yan, J., Crouch, J. H. (2010). Conserving and enhancing maize genetic resources as global public goods: A perspective from CIMMYT. Crop Sci., 50, 13-28. 
Reynolds, M. P., Borlaug, N. E. (2006). International collaborative wheat improvement: Impacts and future prospects. J. Agric. Sci. (Cambridge), 144, 3-17.

Salhuana, W., Pollak, L. (2006). Latin American maize project (LAMP) and germplasm enhancement of maize (GEM) project: Generating useful breeding germplasm. Maydica, 51, 339-355.

Salhuana W., Sevilla, R., Eberhart, S. E. (eds.) (1997). Latin American Maize Project Final Report. Miami, Florida: LAMP; Lima, Perś - Ames, Iowa.
Simmonds, N.W. (1993). Introgression and incorporation: Strategies for the use of crop genetic resources. Biol. Rev., 68, 539-562.

Taba, S., Díaz, J., Franco, J., Crossa, J., Eberhart, S. A. (1999). A Core Subset of LAMP from the Latin American Maize Project. CD-Rom. Centro Internacional de Mejoramiento de Maíz y Trigo, México D.F.

Trethowan, R. M., Reynolds, M. P., Ortiz-Monasterio I., Ortiz R. (2007). The genetic basis of the Green Revolution in wheat production. Plant Breed. Rev., 28, 39-58.

Received 10 September 2012

MAKŠĶERĒŠANA SELEKCIJAS MATERIĀLĀ: PARTNERU ATTIECĪBAS AUGU ĢENĒTISKO RESURSU SAGLABĀŠANAI, PAAUGSTINOT ĢENĒTISKĀ MATERIĀLA DAUDZVEIDĪBU

Būtiska un ilgtspējīga lauksaimniecisko augu ražības paaugstināšana ir nepieciešama sakarā ar sprādzienveidīgu ekonomikas izaugsmi 21. gadsimtā. Tā panākama ar augu selekcijas palīdzību, sadarbojoties daudzu valstu partneriem. Apskata rakstā aplūkoti vairāki veiksmīgi starptautiskās sadarbības piemēri svarīgāko lauksaimniecības augu selekcijā. 